九州大学学術情報リポジトリ

Kyushu University Institutional Repository

\title{
Extractability of Heavy Metals in Sediments and Farmland Soil in the To Lich and Kim Nguu River System
}

Nguyen, Thi Lan Huong

Laboratory of Environmental Soil Engineering, Division of Bioproduction Environmental

Sciences, Department of Agro-environmental Sciences, Graduate School of Bioresource and

Bioenvironmental Sciences, Kyushu University

Ohtsubo, Masami

Higashi, Takahiro

Kanayama, Motohei

https://doi.org/10.5109/20337

出版情報 : 九州大学大学院農学研究院紀要. 56 (2)，pp. 395-399，2011-09. 九州大学大学院農学研究院 バージョン：

権利関係 : 


\title{
Extractability of Heavy Metals in Sediments and Farmland Soil in the To Lich and Kim Nguu River System
}

\author{
NGUYEN Thi Lan Huong', Masami OHTSUBO*, Takahiro HIGASHI \\ and Motohei KANAYAMA
}

\author{
Laboratory of Environmental Soil Engineering, Division of Bioproduction Environmental Sciences, \\ Department of Agro-environmental Sciences, Faculty of Agriculture, \\ Kyushu University, Fukuoka, 812-8581, Japan \\ (Received April 28, 2011 and accepted May 9, 2011)
}

\begin{abstract}
The purpose of the present study was to evaluate the availability and mobility of heavy metals in sediments and farmland soils in the To Lich and Kim Nguu River system through the amount of heavy metals extracted with acids and its percentage to total metal concentration. Twelve sediment samples were collected from the To-Lich, Kim-Nguu River and 19 soil samples were colleted at two different locations in agricultural field and pappy field along the river. The results showed that the highest amount of heavy metals extracted from the sediment samples with $0.5 \mathrm{M} \mathrm{HCl}$ and $0.1 M \mathrm{HNO}_{3}$ was in the order of $\mathrm{Zn}>\mathrm{Cr}>\mathrm{Cu}$ $>\mathrm{Pb}>\mathrm{Ni}>\mathrm{Cd}$ and $\mathrm{Cr}>\mathrm{Zn}>\mathrm{Ni}>\mathrm{Cu}>\mathrm{Pb}>\mathrm{Cd}$, respectively. The average percentage of the amount of extractable metals to the total metal concentration for the agricultural soil was the highest for Ni (70\%), followed by $\mathrm{Cr}(65 \%), \mathrm{Cd}(50 \%), \mathrm{Zn}(20 \%), \mathrm{Pb}(10 \%)$ and $\mathrm{Cu}(7 \%)$, suggesting that Ni is more labile and available to plants than other elements. The average percentage for the paddy soil was the highest for $\mathrm{Cr}$ (75\%), followed by $\mathrm{Ni}(50 \%)$, Cd (40\%), Zn (30\%), Pb (20\%) and Cu (15\%), suggesting the highest availability of Cr to plants.

In general, the amount of the extracted heavy metals was similar between the agricultural and paddy soil. The amount of heavy metals extracted with $0.5 \mathrm{M} \mathrm{HCl}$ was greater than that extracted with $0.1 M \mathrm{HNO}_{3}$ for all metals except Cr.
\end{abstract}

Keywords: extracted heavy metals, availability of heavy metals, agricultural soils

\section{INTRODUCTION}

To predict the availability of heavy metals to plants, the extractability of heavy metals from soils and sediments with various chemical reagents has been assessed. Amacher (1996), and Filipek and Pawlowski (1990) recommended $\mathrm{HCl}$ as one of the extractants to estimate plant-available Ni, Cd, and Pb in soil. Yania et al. (1998) also showed that tenth molar $(0.1 M) \mathrm{HCl}$ had been widely used to evaluate the availability of heavy metals in soils and sediments.

The physiochemical characteristics of soil and sediment, and the type of acid for extraction influence the amount of heavy metals extracted. In addition, the ratio of soil and sediment to extractant solution is one of the most important factors that control the amount of heavy metals extracted. Many researchers used 1/5 for the ratio of solid to extractant solution in extracting heavy metals from soils and sediments using $0.1 \mathrm{M} \mathrm{HCl}$ and other acids.

There are two rivers in Hanoi City, the To Lich and Kim Nguu River, which are the main source of irrigation water for suburban agricultural land and fish farming pond. The industrial wastewater discharged into the rivers has degraded the quality of sediments in the river system. This has affected not only farming and fish breed-

\footnotetext{
Laboratory of Environmental Soil Engineering, Division of Bioproduction Environmental Sciences, Department of Agroenvironmental Sciences, Graduate School of Bioresource and Bioenvironmental Sciences, Kyushu University

* Corresponding author (E-mail: ohtsubo@bpes.kyushu-u.ac.jp)
}

ing, but also the health of general public in surrounding areas.

The present study was conducted to evaluate the availability and mobility of heavy metals in the sediments and agricultural soils in the To Lich and Kim Nguu River system through the amount of metals obtained by acid treatment and its percentage to total metal concentration.

\section{MATERIALS AND METHODS}

\section{Materials}

Twelve sediment samples $(S D)$ were collected from the To-Lich and Kim-Nguu River and 19 soil samples were colleted at two different locations: location 1 (agricultural field) and location 2 (pappy field) at Van Dien area of Hanoi City on December 3 to 6 of 2005 (Fig. 1). Sediment samples were collected from the surface zone $(20 \mathrm{~cm})$ of the sediment at the 12 sites submerged with water (Table 1). The core samples of $90 \mathrm{~cm}$ depth were also taken at 2 sites where sediment surface was exposed to the air.

Eight soil samples (SS) were colleted from location 1- agricultural field from the depths of 0-20, 20-40 and $40-60 \mathrm{~cm}$ at the locations of various distances from the canal: 0, 20 and $60 \mathrm{~m}$.

Another eleven soil samples were colleted from location 2- paddy field near roadside at $0,3,5,10,20$ and $50 \mathrm{~m}$ from the edge of the road (Table 2). Also samples were taken from the depths of $0-20$ and $20-40 \mathrm{~cm}$ at the locations of various distances from the road: $0,3,6,10,20$ and $50 \mathrm{~m}$. They were brought to Japan after air - drying, 


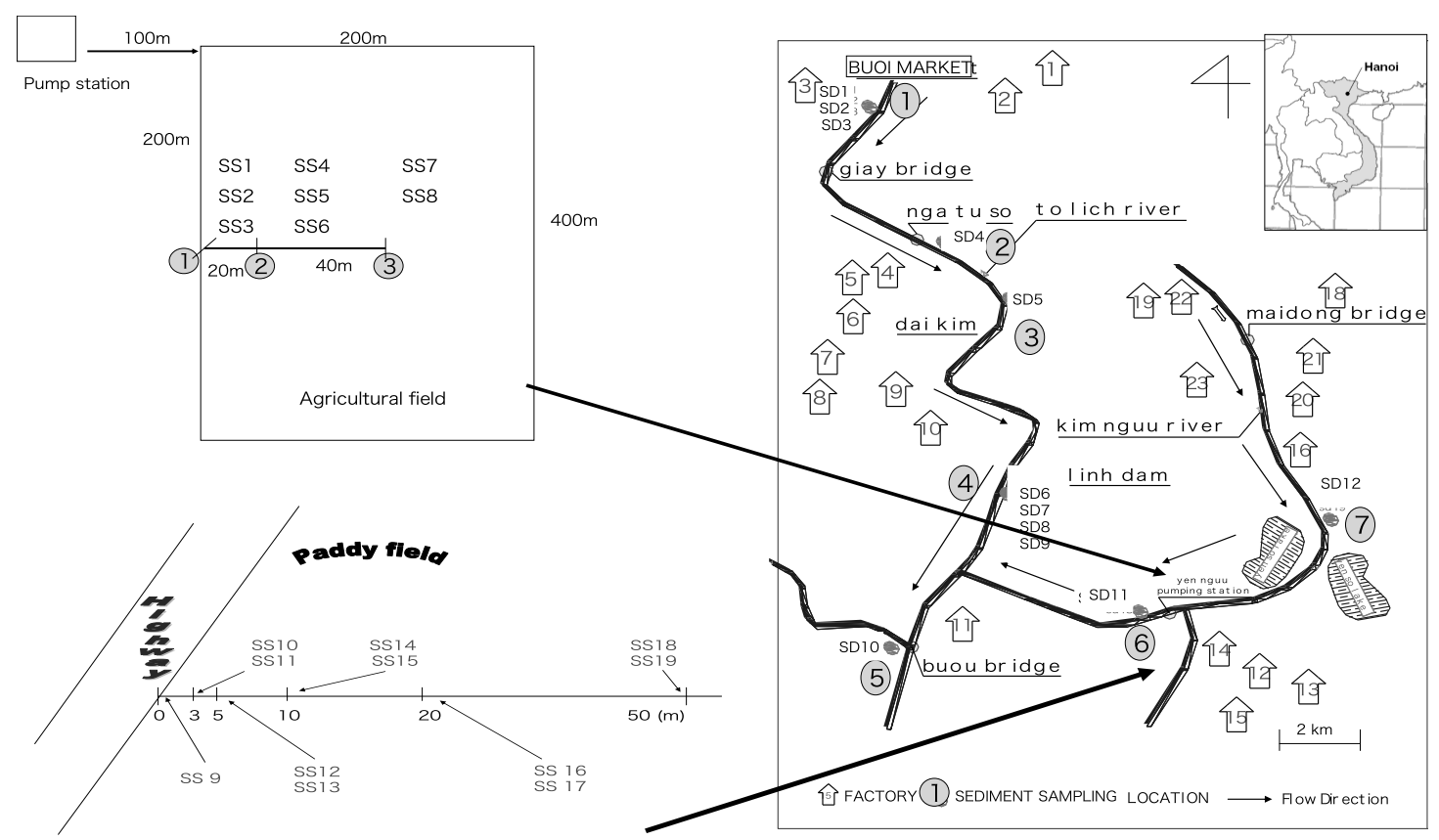

Fig. 1. Sampling location.

Table 1. Total concentrations of $\mathrm{Cd}, \mathrm{Cr}$ and $\mathrm{Cu}$ in the sediment samples and the amount of metals extracted with acids (mg/kg)

\begin{tabular}{|c|c|c|c|c|c|c|c|c|c|c|}
\hline \multirow{2}{*}{ No } & \multirow{2}{*}{$\begin{array}{c}\text { Depth } \\
(\mathrm{cm})\end{array}$} & \multicolumn{3}{|c|}{$\mathrm{Cd}$} & \multicolumn{3}{|c|}{$\mathrm{Cr}$} & \multicolumn{3}{|c|}{$\mathrm{Cu}$} \\
\hline & & Total & $0.5 \mathrm{M} \mathrm{HCl}$ & $0.1 \mathrm{MHNO}_{3}$ & Total & $0.5 \mathrm{M} \mathrm{HCl}$ & $0.1 M \mathrm{HNO}_{3}$ & Total & $0.5 M \mathrm{HCl}$ & $0.1 \mathrm{MHNO}$ \\
\hline SD 1 & $0-30$ & 4.4 & 1.4 & 1.2 & 260 & 115 & 160 & 250 & 77 & 5 \\
\hline SD 2 & $30-60$ & 5.3 & 3.0 & 2.4 & 320 & 120 & 181 & 441 & 64 & 3 \\
\hline SD 3 & $60-90$ & 5.2 & 2.5 & 2.1 & 345 & 111 & 146 & 345 & 37 & 9 \\
\hline SD 4 & $0-20$ & 20 & 10.1 & 12.6 & 472 & 112 & 143 & 478 & 105 & 6 \\
\hline SD 5 & $0-20$ & 40 & 29.9 & 25.8 & 445 & 101 & 132 & 490 & 96 & 5 \\
\hline SD 6 & $0-20$ & 2.7 & 2.8 & 2.2 & 357 & 121 & 158 & 422 & 64 & 9 \\
\hline SD 7 & $0-30$ & 2.5 & 1.5 & 1.2 & 340 & 137 & 155 & 395 & 37 & 4 \\
\hline SD 8 & $30-60$ & 3.7 & 2.6 & 1.7 & 220 & 131 & 152 & 370 & 48 & 21 \\
\hline SD 9 & 60-90 & 2.7 & 1.8 & 1.6 & 240 & 112 & 147 & 325 & 50 & 27 \\
\hline SD 10 & 0-20 & 8.5 & 5.5 & 3.6 & 401 & 115 & 159 & 324 & 52 & 28 \\
\hline SD 11 & $0-20$ & 17 & 11.4 & 11.1 & 415 & 103 & 135 & 535 & 101 & 5 \\
\hline SD 12 & $0-20$ & 3.5 & 2.4 & 1.9 & 475 & 105 & 141 & 520 & 114 & 5 \\
\hline
\end{tabular}

Table 2. Total concentrations of $\mathrm{Ni}, \mathrm{Pb}$ and $\mathrm{Zn}$ in the sediment samples and the amount of metals extracted with acids (mg/kg)

\begin{tabular}{|c|c|c|c|c|c|c|c|c|c|c|}
\hline \multirow{2}{*}{ No } & \multirow{2}{*}{$\begin{array}{c}\text { Depth } \\
(\mathrm{cm})\end{array}$} & \multicolumn{3}{|c|}{$\mathrm{Ni}$} & \multicolumn{3}{|c|}{$\mathrm{Pb}$} & \multicolumn{3}{|c|}{$\mathrm{Zn}$} \\
\hline & & Total & $0.5 \mathrm{M} \mathrm{HCl}$ & $0.1 M \mathrm{HNO}_{3}$ & Total & $0.5 \mathrm{M} \mathrm{HCl}$ & $0.1 M \mathrm{HNO}_{3}$ & Total & $0.5 \mathrm{M} \mathrm{HCl}$ & $0.1 \mathrm{M} \mathrm{HNO}$ \\
\hline SD 1 & $0-30$ & 65 & 24 & 17 & 368 & 58 & 6 & 250 & 201 & 26 \\
\hline SD 2 & $30-60$ & 63 & 22 & 15 & 395 & 46 & 1 & 441 & 187 & 21 \\
\hline SD 3 & 60-90 & 48 & 15 & 10 & 425 & 42 & 2 & 345 & 173 & 18 \\
\hline SD 4 & $0-20$ & 165 & 58 & 31 & 490 & 101 & 3 & 478 & 262 & 17 \\
\hline SD 5 & $0-20$ & 108 & 44 & 25 & 450 & 46 & 3 & 490 & 223 & 31 \\
\hline SD 6 & $0-20$ & 57 & 31 & 19 & 348 & 42 & 3 & 422 & 203 & 171 \\
\hline SD 7 & $0-30$ & 52 & 14 & 15 & 280 & 28 & 1 & 395 & 83 & 98 \\
\hline SD 8 & $30-60$ & 58 & 18 & 10 & 260 & 45 & 12 & 370 & 117 & 64 \\
\hline SD 9 & 60-90 & 50 & 19 & 11 & 370 & 52 & 12 & 325 & 106 & 55 \\
\hline SD 10 & $0-20$ & 64 & 30 & 19 & 435 & 45 & 6 & 324 & 149 & 131 \\
\hline SD 11 & $0-20$ & 142 & 44 & 32 & 430 & 212 & 1 & 535 & 241 & 207 \\
\hline SD 12 & $0-20$ & 151 & 45 & 32 & 665 & 37 & 1 & 520 & 225 & 197 \\
\hline
\end{tabular}


and then ground, passed through a 1-mm sieve, and preserved in plastic bottles.

\section{Methods}

Both $0.5 \mathrm{M} \mathrm{HCl}$ and $0.1 \mathrm{M} \mathrm{HNO}_{3}$ were used to extract heavy metals from the sediments and agricultural soils. Heavy metal extraction was made on suspensions with the ratio of solid to extractant solution of 1:5. Five $g$ airdried sediment and soil, and $25 \mathrm{ml} 0.5 \mathrm{M} \mathrm{HCl}$ and $0.1 \mathrm{M}$ $\mathrm{HNO}_{3}$ were used. The suspensions were agitated continuously for an hour and then centrifuged at 2,500 rpm for $10 \mathrm{~min}$. The supernatant was separated and analyzed for the concentration of $\mathrm{Cd}, \mathrm{Cr}, \mathrm{Cu}, \mathrm{Ni}, \mathrm{Pb}$ and $\mathrm{Zn}$ by atomic absorption spectrophotometer $(A A S)$.

For total metal concentration, heavy metals in the sediment was digested with $1 \mathrm{M} \mathrm{HNO}_{3}$ at $96^{\circ} \mathrm{C}$ for an hour and centrifuged, and dissolved metals in the supernatant were analyzed by atomic absorption spectrophotometer (Committee of Soil standard methods for Analyses and Measurement, 1986).

The determination of metal concentrations was made in duplicate and the relative deviation of the duplicate values was mostly less than $5 \%$.

\section{RESULTS AND DISCUSSIONS}

\section{Sediment samples}

The amount of heavy metals extracted with $0.5 \mathrm{M}$ $\mathrm{HCl}$ and $0.1 \mathrm{M} \mathrm{HNO}_{3}$ are shown in Tables 1 and 2 along with the total heavy metals determined by the extraction with concentrated $\mathrm{HNO}_{3}$ (Huong et al., 2008). As a whole, the highest amount of metals extracted was in the order of $\mathrm{Zn}>\mathrm{Cr}>\mathrm{Cu}>\mathrm{Pb}>\mathrm{Ni}>\mathrm{Cd}$ for $0.5 \mathrm{M} \mathrm{HCl}$ and of $\mathrm{Cr}$ $>\mathrm{Zn}>\mathrm{Ni}>\mathrm{Cu}>\mathrm{Pb}>\mathrm{Cd}$ for $0.1 M \mathrm{HNO}_{3}$.

The Cd extracted with $0.5 \mathrm{M} \mathrm{HCl}$ and $0.1 \mathrm{M} \mathrm{HNO}_{3}$ was in an extremely wide range between 1.4 and $39.9 \mathrm{mg} / \mathrm{kg}$ and 1.2 and $25.8 \mathrm{mg} / \mathrm{kg}$, respectively. The Cd extracted with $0.5 \mathrm{M} \mathrm{HCl}$ was slightly higher than that with $0.1 \mathrm{M}$ $\mathrm{HNO}_{3}$ in most samples. The extracted Cd for $\mathrm{SD} 4,5$ and 11 were much greater compared to other samples, which was as much as $50 \%$ of the total Cd concentration. A significant correlation coefficient was obtained between the extractable and total Cd for both acids in all samples. The greater extracted heavy metals in $S D$ 4, 5 and 11 would be due to the higher total heavy metal concentrations. In general, the mobility and extractability of $\mathrm{Cd}$ in the sediment was very high.

The $\mathrm{Cr}$ extracted with $0.5 \mathrm{M} \mathrm{HCl}$ and $0.1 \mathrm{M} \mathrm{HNO}_{3}$ was in a range of 101 to $137 \mathrm{mg} / \mathrm{kg}$ and 132 to $181 \mathrm{mg} / \mathrm{kg}$, which was $15-20 \%$ of the total heavy metal concentration. The $\mathrm{Cd}$ extracted with $0.5 \mathrm{M} \mathrm{HCl}$ tended to be slightly smaller than that with $0.1 M \mathrm{HNO}_{3}$. There was not much difference in the amount of available heavy metals among the samples. The correlation between extractable and total Cd was not significant for both extractants.

The extracted $\mathrm{Cu}$ ranged from 37 to $105 \mathrm{mg} / \mathrm{kg}$ for $0.5 \mathrm{M} \mathrm{HCl}$ and 3 to $28 \mathrm{mg} / \mathrm{kg}$ for $0.1 \mathrm{M} \mathrm{HNO}_{3}$, which was $10-30 \%$ and $1-10 \%$ of the total heavy metal concentration, respectively. The $\mathrm{Cu}$ extracted with $0.5 \mathrm{M} \mathrm{HCl} \mathrm{was}$ 5 to 10 times greater than that with $0.1 M \mathrm{HNO}_{3}$. Much difference in the amount of available heavy metals among the samples would be due to the difference in the extracted total heavy metals. A correlation between extractable and total concentration was not significant for both extractants.

In Table 2, the amount of extractable $\mathrm{Ni}$ and its percentage of total metal concentration were similar between $0.1 \mathrm{M} \mathrm{HNO}_{3}$ and $0.5 \mathrm{M} \mathrm{HCl}$ with the range of $10-50 \mathrm{mg} / \mathrm{kg}$ and $20-50 \%$. The correlation between the extractable metal and total metal concentration was significant for both extractants. The samples with higher total heavy metal concentrations gave higher amount of extracted Ni for $S D 4,5,11,12$.

For the extracted $\mathrm{Pb}$, big differences were found among the samples and between the extractants. The $\mathrm{Pb}$ extracted with $0.5 \mathrm{M} \mathrm{HCl}$ was 10 times greater than that with $0.1 M \mathrm{HNO}_{3}$. Extractable $\mathrm{Pb}$ was in a range of $28-212 \mathrm{mg} / \mathrm{kg}$ for $0.5 \mathrm{M} \mathrm{HCl}$ and $1-12 \mathrm{mg} / \mathrm{kg}$ for $0.1 \mathrm{M}$ $\mathrm{HNO}_{3}$, which was $10-20 \%$ and $1-5 \%$ of total $\mathrm{Pb}$ concentration, respectively. The correlation between extractable and total concentration was significant for $0.5 \mathrm{M} \mathrm{HCl}$ but not for $0.1 \mathrm{M} \mathrm{HNO}_{3}$.

The amount of extracted Zn exhibited big differences among the samples for both extractants, with a range of $83-262 \mathrm{mg} / \mathrm{kg}$ for $0.5 \mathrm{M} \mathrm{HCl}$ and $17-207 \mathrm{mg} / \mathrm{kg}$ for $0.1 \mathrm{M}$ $\mathrm{HNO}_{3}$.

\section{Soil samples}

The total heavy metals concentration in the soil of suburban farmland in Hanoi indicates that the soil has been polluted with heavy metals through the irrigation of water from the To-Lich and Kim-Nguu River (Huong et al., $2008 \mathrm{a}, \mathrm{b}$ ). The amount of extractable heavy metals in the agricultural and paddy soil used for the above study is shown in Tables 3, 4, 5 and 6.

The amount of extracted heavy metals of agricultural soil (Table 3 and 4) extracted with $0.5 \mathrm{M} \mathrm{HCl}$ and $0.1 \mathrm{M} \mathrm{HNO}_{3}$ was in the range of $2-3.3 \mathrm{mg} / \mathrm{kg}$ and $1.6-$ $2.1 \mathrm{mg} / \mathrm{kg}$ for $\mathrm{Cd}, 108-124 \mathrm{mg} / \mathrm{kg}$ and $136-161 \mathrm{mg} / \mathrm{kg}$ for Cr, 20-45 mg/kg and 9-17 mg/kg for $\mathrm{Cu}$, both $15-55 \mathrm{mg} /$ $\mathrm{kg}$ for $\mathrm{Ni}, 21-46 \mathrm{mg} / \mathrm{kg}$ and $1-7.6 \mathrm{mg} / \mathrm{kg}$ for $\mathrm{Pb}$, and $45-57 \mathrm{mg} / \mathrm{kg}$ and $21-45 \mathrm{mg} / \mathrm{kg}$ for $\mathrm{Zn}$.

The heavy metals in paddy soils (Table 5 and 6 ) extracted with $0.5 \mathrm{M} \mathrm{HCl}$ and $0.1 \mathrm{M} \mathrm{HNO}_{3}$ was in the range of $2-2.8 \mathrm{mg} / \mathrm{kg}$ and 1.6 to $2.4 \mathrm{mg} / \mathrm{kg}$ for $\mathrm{Cd}, 102$ $128 \mathrm{mg} / \mathrm{kg}$ and $137-155 \mathrm{mg} / \mathrm{kg}$ for $\mathrm{Cr}, 31-50 \mathrm{mg} / \mathrm{kg}$ and $5-25 \mathrm{mg} / \mathrm{kg}$ for $\mathrm{Cu}, 5-24$ and $4-11 \mathrm{mg} / \mathrm{kg}$ for $\mathrm{Ni}$, $15-38 \mathrm{mg} / \mathrm{kg}$ and $1-4 \mathrm{mg} / \mathrm{kg}$ for $\mathrm{Pb}$, and $40-93 \mathrm{mg} / \mathrm{kg}$ and $11-41 \mathrm{mg} / \mathrm{kg}$ for Zn.

The average percentage of the amount of extractable metals to the total metal concentration for the agricultural soil was the highest for $\mathrm{Ni}(70 \%)$, followed by $\mathrm{Cr}$ (65\%), Cd (50\%), Zn (20\%), Pb (10\%) and Cu (7\%), suggesting that $\mathrm{Ni}$ is more labile and available to plants than other elements. The average percentage for the paddy soil was the highest for $\mathrm{Cr}$ (75\%), followed by Ni (50\%), Cd (40\%), Zn (30\%), Pb (20\%) and Cu (15\%), suggesting the highest availability of Cr to plants.

In general, the amount of the extracted heavy metals was similar between the agricultural and paddy soil. 
Table 3. Total concentrations of $\mathrm{Cd}, \mathrm{Cr}$ and $\mathrm{Cu}$ in the soil samples of the agricultural field and the amount of metals extracted with acids $(\mathrm{mg} / \mathrm{kg})$

\begin{tabular}{|c|c|c|c|c|c|c|c|c|c|c|}
\hline \multirow{2}{*}{ No } & \multirow{2}{*}{$\begin{array}{c}\text { Depth } \\
(\mathrm{cm})\end{array}$} & \multicolumn{3}{|c|}{$\mathrm{Cd}$} & \multicolumn{3}{|c|}{$\mathrm{Cr}$} & \multicolumn{3}{|c|}{$\mathrm{Cu}$} \\
\hline & & Total & $0.5 M \mathrm{HCl}$ & $0.1 M \mathrm{HNO}_{3}$ & Total & $0.5 M \mathrm{HCl}$ & $0.1 \mathrm{M} \mathrm{HNO}_{3}$ & Total & $0.5 \mathrm{M} \mathrm{HCl}$ & $0.1 \mathrm{M} \mathrm{HNO}_{3}$ \\
\hline SS 1 & $0-20$ & 4.5 & 3.3 & 2.1 & 190 & 108 & 158 & 230 & 45 & 17 \\
\hline SS 2 & $20-40$ & 4.0 & 2.0 & 1.9 & 190 & 134 & 161 & 200 & 29 & 12 \\
\hline SS 3 & 40-60 & 4.1 & 2.3 & 1.9 & 172 & 126 & 139 & 195 & 34 & 10 \\
\hline SS 4 & $0-20$ & 4.0 & 2.3 & 1.9 & 170 & 112 & 145 & 218 & 40 & 15 \\
\hline SS 5 & $20-40$ & 4.0 & 2.0 & 1.8 & 178 & 109 & 155 & 185 & 26 & 11 \\
\hline SS 6 & $40-60$ & 3.7 & 2.0 & 1.6 & 145 & 104 & 136 & 170 & 32 & 10 \\
\hline SS 7 & $0-20$ & 3.9 & 2.3 & 2.0 & 185 & 124 & 154 & 208 & 39 & 17 \\
\hline SS 8 & $20-40$ & 3.9 & 2.2 & 1.6 & 172 & 115 & 145 & 162 & 20 & 9 \\
\hline
\end{tabular}

Table 4. Total concentrations of $\mathrm{Ni}, \mathrm{Pb}$ and $\mathrm{Zn}$ in the soil samples of the agricultural field and the amount of metals extracted with acids $(\mathrm{mg} / \mathrm{kg})$

\begin{tabular}{|c|c|c|c|c|c|c|c|c|c|c|}
\hline \multirow{2}{*}{ No } & \multirow{2}{*}{$\begin{array}{c}\text { Depth } \\
(\mathrm{cm})\end{array}$} & \multicolumn{3}{|c|}{$\mathrm{Ni}$} & \multicolumn{3}{|c|}{$\mathrm{Pb}$} & \multicolumn{3}{|c|}{$\mathrm{Zn}$} \\
\hline & & Total & $0.5 \mathrm{M} \mathrm{HCl}$ & $0.1 \mathrm{M} \mathrm{HNO}_{3}$ & Total & $0.5 \mathrm{M} \mathrm{HCl}$ & $0.1 \mathrm{M} \mathrm{HNO}_{3}$ & Total & $0.5 \mathrm{M} \mathrm{HCl}$ & $0.1 \mathrm{M} \mathrm{HNO}_{3}$ \\
\hline SS 1 & $0-20$ & 80 & 55 & 18 & 145 & 46 & 0.9 & 263 & 57 & 45 \\
\hline SS 2 & $20-40$ & 59 & 20 & 11 & 138 & 23 & 3.1 & 190 & 47 & 35 \\
\hline SS 3 & 40-60 & 65 & 21 & 12 & 135 & 29 & 5.0 & 195 & 52 & 22 \\
\hline SS 4 & $0-20$ & 74 & 51 & 15 & 130 & 36 & 1.3 & 255 & 54 & 55 \\
\hline SS 5 & $20-40$ & 56 & 41 & 11 & 132 & 20 & 5.0 & 183 & 46 & 30 \\
\hline SS 6 & 40-60 & 58 & 46 & 11 & 126 & 25 & 6.8 & 182 & 50 & 20 \\
\hline SS 7 & $0-20$ & 45 & 16 & 9 & 125 & 33 & 6.6 & 187 & 56 & 27 \\
\hline SS 8 & $20-40$ & 42 & 15 & 8 & 120 & 21 & 7.6 & 178 & 45 & 21 \\
\hline
\end{tabular}

Table 5. Total concentrations of $\mathrm{Cd}, \mathrm{Cr}$ and $\mathrm{Cu}$ in the soil samples of the paddy field and the amount of metals extracted with acids $(\mathrm{mg} / \mathrm{kg})$

\begin{tabular}{|c|c|c|c|c|c|c|c|c|c|c|}
\hline \multirow{2}{*}{ No } & \multirow{2}{*}{$\begin{array}{c}\text { Depth } \\
(\mathrm{cm})\end{array}$} & \multicolumn{3}{|c|}{$\mathrm{Cd}$} & \multicolumn{3}{|c|}{$\mathrm{Cr}$} & \multicolumn{3}{|c|}{$\mathrm{Cu}$} \\
\hline & & Total & $0.5 \mathrm{M} \mathrm{HCl}$ & $0.1 \mathrm{M} \mathrm{HNO}_{3}$ & Total & $0.5 \mathrm{M} \mathrm{HCl}$ & $0.1 \mathrm{M} \mathrm{HNO}_{3}$ & Total & $0.5 \mathrm{M} \mathrm{HCl}$ & $0.1 \mathrm{M} \mathrm{HNO}_{3}$ \\
\hline SS 9 & $0-20$ & 7.5 & 2.0 & 1.8 & 201 & 110 & 146 & 270 & 50 & 25 \\
\hline SS 10 & $0-20$ & 4.5 & 2.8 & 2.4 & 195 & 112 & 155 & 225 & 39 & 16 \\
\hline SS 11 & $20-40$ & 4 & 2.1 & 1.9 & 190 & 121 & 154 & 245 & 25 & 10 \\
\hline SS 12 & $0-20$ & 4.5 & 2.6 & 2.2 & 195 & 108 & 150 & 220 & 35 & 15 \\
\hline SS 13 & $20-40$ & 3.5 & 2.2 & 2.1 & 178 & 106 & 145 & 190 & 31 & 9 \\
\hline SS 14 & $0-20$ & 4.5 & 2.5 & 2.1 & 195 & 110 & 148 & 192 & 38 & 14 \\
\hline SS 15 & $20-40$ & 3 & 2.1 & 2.0 & 166 & 102 & 140 & 175 & 32 & 7 \\
\hline SS 16 & $0-20$ & 4 & 2.3 & 2.0 & 193 & 115 & 147 & 190 & 40 & 16 \\
\hline SS 17 & $20-40$ & 2.9 & 2.1 & 1.8 & 165 & 116 & 140 & 165 & 35 & 7 \\
\hline SS 18 & $0-20$ & 4 & 2.1 & 2.0 & 192 & 128 & 147 & 190 & 43 & 13 \\
\hline SS 19 & $20-40$ & 3 & 2.0 & 1.6 & 162 & 120 & 137 & 155 & 36 & 5 \\
\hline
\end{tabular}

Table 6. Total concentrations of $\mathrm{Ni}, \mathrm{Pb}$ and $\mathrm{Zn}$ in the soil samples of the paddy field and the amount of metals extracted with acids $(\mathrm{mg} / \mathrm{kg})$

\begin{tabular}{|c|c|c|c|c|c|c|c|c|c|c|}
\hline \multirow{2}{*}{ No } & \multirow{2}{*}{$\begin{array}{c}\text { Depth } \\
\text { (cm) }\end{array}$} & \multicolumn{3}{|c|}{$\mathrm{Ni}$} & \multicolumn{3}{|c|}{$\mathrm{Pb}$} & \multicolumn{3}{|c|}{$\mathrm{Zn}$} \\
\hline & & Total & $0.5 \mathrm{M} \mathrm{HCl}$ & $0.1 \mathrm{M} \mathrm{HNO}_{3}$ & Total & $0.5 \mathrm{M} \mathrm{HCl}$ & $0.1 \mathrm{M} \mathrm{HNO}_{3}$ & Total & $0.5 M \mathrm{HCl}$ & $0.1 \mathrm{M} \mathrm{HNO}_{3}$ \\
\hline SS 9 & $0-20$ & 58 & 13 & 6 & 195 & 38 & 2 & 310 & 93 & 41 \\
\hline SS 10 & $0-20$ & 56 & 24 & 11 & 175 & 36 & 1 & 256 & 84 & 38 \\
\hline SS 11 & $20-40$ & 40 & 7 & 8 & 160 & 20 & 4 & 165 & 49 & 17 \\
\hline SS 12 & $0-20$ & 51 & 23 & 10 & 165 & 35 & 1 & 200 & 80 & 34 \\
\hline SS 13 & $20-40$ & 40 & 8 & 9 & 155 & 20 & 3 & 165 & 46 & 15 \\
\hline SS 14 & $0-20$ & 50 & 20 & 8 & 165 & 33 & 1 & 183 & 77 & 31 \\
\hline SS 15 & $20-40$ & 37 & 8 & 7 & 145 & 19 & 4 & 163 & 45 & 15 \\
\hline SS 16 & $0-20$ & 48 & 19 & 7 & 160 & 31 & 1 & 175 & 74 & 26 \\
\hline SS 17 & 20-40 & 36 & 7 & 6 & 140 & 17 & 4.0 & 163 & 43 & 13 \\
\hline SS 18 & 0-20 & 46 & 15 & 7 & 155 & 30 & 1.0 & 165 & 71 & 21 \\
\hline SS 19 & $20-40$ & 32 & 5 & 4 & 130 & 15 & 3 & 162 & 40 & 11 \\
\hline
\end{tabular}


The amount of heavy metals extracted with $0.5 \mathrm{M} \mathrm{HCl}$ was greater than that extracted with $0.1 \mathrm{M} \mathrm{HNO}_{3}$ for all metals except $\mathrm{Cr}$.

\section{CONCLUSIONS}

The amount of heavy metals extracted from the river sediments and farmland soil depended on the type of extractants and heavy metals. The highest amount of heavy metals extracted from the sediment samples was in the order of $\mathrm{Zn}>\mathrm{Cr}>\mathrm{Cu}>\mathrm{Pb}>\mathrm{Ni}>\mathrm{Cd}$ for $0.5 M$ $\mathrm{HCl}$ and $\mathrm{Cr}>\mathrm{Zn}>\mathrm{Ni}>\mathrm{Cu}>\mathrm{Pb}>\mathrm{Cd}$ for $0.1 M \mathrm{HNO}_{3}$. In general, the amount of extracted heavy metals was similar between agricultural and paddy soils. The amount of heavy metals extracted with $0.5 \mathrm{M} \mathrm{HCl}$ was greater than that extracted with $0.1 \mathrm{M} \mathrm{HNO}_{3}$ for all metals except $\mathrm{Cr}$.

\section{REFERENCES}

Amacher, M. C. 1996 Nikel, Cadmium, and Lead In Methods of Soil Analysis, Part 3: Chemical Methods; Sparks, D. L.,
Ed., Soil Science Society of America, Madison, WI: 739-768 Committee of Soil Standard Methods for Analyses and Measurements 1986 Soil Standard Methods for Analyses and Measurements. Hakuyusha, Tokyo

Filipek, T. and L. Pawlowski 1990 Total and extractable heavy metal content of some soils of the Lublin coal mining region. Journal of Total Environment, 96: 131-137

Nguyen, T. L. H., M. Ohtsubo, Y. Li Loretta, T. Higashi and M. Kanayama 2010a Heavy metal contamination of soil and vegetable in wastewater-irrigated agricultural field in a suburban area of Hanoi, Vietnam. Communications in Soil Science and Plant analysis, 41(4): 290-307

Nguyen, T. L. H., M. Ohtsubo, Y. Li Loretta, T. Higashi and M. Kanayama 2010b Heavy metal contamination of river sediments in Hanoi, Vietnam. Water Management, 163(3): $111-121$

Nguyen, T. L. H., M. Ohtsubo, Y. Li Loretta, T. Higashi and M. Kanayama 2008 Heavy metal contamination of soil and rice in wastewater-irrigated paddy field in a suburban area of Hanoi, Vietnam. Clay Science, 13: 205-215

Yanai, J., M. Yabutani, K. Yumei, B. Huang, G. Luo and T. Kosaki 1998 Heavy Metal Pollution of Agricultural Soils and Sediments in Liaoning Province, China. Journal of Soil Science and Plant Nutrient, 4: 367-375 